\title{
Skill Obsolescence, Lifelong Learning and Labor Market Participation
}

Citation for published version (APA):

Allen, J. P., \& de Grip, A. (2007). Skill Obsolescence, Lifelong Learning and Labor Market Participation. ROA. ROA Research Memoranda No. 006 https://doi.org/10.26481/umaror.2007006

Document status and date:

Published: 01/01/2007

DOI:

10.26481/umaror.2007006

Document Version:

Publisher's PDF, also known as Version of record

\section{Please check the document version of this publication:}

- A submitted manuscript is the version of the article upon submission and before peer-review. There can be important differences between the submitted version and the official published version of record.

People interested in the research are advised to contact the author for the final version of the publication, or visit the DOI to the publisher's website.

- The final author version and the galley proof are versions of the publication after peer review.

- The final published version features the final layout of the paper including the volume, issue and page numbers.

Link to publication

\footnotetext{
General rights rights.

- You may freely distribute the URL identifying the publication in the public portal. please follow below link for the End User Agreement:

www.umlib.nl/taverne-license

Take down policy

If you believe that this document breaches copyright please contact us at:

repository@maastrichtuniversity.nl

providing details and we will investigate your claim.
}

Copyright and moral rights for the publications made accessible in the public portal are retained by the authors and/or other copyright owners and it is a condition of accessing publications that users recognise and abide by the legal requirements associated with these

- Users may download and print one copy of any publication from the public portal for the purpose of private study or research.

- You may not further distribute the material or use it for any profit-making activity or commercial gain

If the publication is distributed under the terms of Article $25 \mathrm{fa}$ of the Dutch Copyright Act, indicated by the "Taverne" license above, 


\title{
Skill Obsolescence, Lifelong Learning and Labor Market Participation
}

\author{
Jim Allen \\ Andries de Grip \\ ROA-RM-2007/6 \\ August 07
}

Research Centre for Education and the Labour Market

P.O. Box 616

6200 MD Maastricht

The Netherlands

E-mail: $\quad$ mailto:secretary@ roa.unimaas.nl

Internet: $\quad$ http://www.roa.unimaas.nl

Maastricht University

Faculty of Economics and Business Administration 
The ROA Research Memorandum Series was created in order to make research results available for discussion, before those results are submitted for publication in journals.

Sec07.091.pdf 
ROA-RM-2007/6 » http://www.roa.unimaas.nl/resmem.htm

\section{Abstract}

\section{Skill Obsolescence, Lifelong Learning and Labor Market Participation ${ }^{1}$}

We analyze whether technological change induces skill obsolescence and early labor market exit, and to what extent lifelong learning reduces these risks. Using panel data on older workers, we find that workers report skill obsolescence more often in jobs in which learning is a structural characteristic. However, perceived skill obsolescence has no significant effect on the probability of losing employment. Instead, workers who experience skill obsolescence participate more often in training, which decreases the risk of losing employment. The results are consistent with the dynamic model of skill obsolescence and employment loss developed in this paper. Moreover, we find that when workers with long job tenures decrease their training participation, this is an early indicator of future job loss.

Keywords: Skill obsolescence, training, technological change, loss of work

Jim Allen

ROA

P.O. Box 616

6200 MD Maastricht

j.allen@ roa.unimaas.nl
Andries de Grip

ROA

P.O. Box 616

6200 MD Maastricht

a.degrip@ roa.unimaas.nl

1. We would like to thank Ben Kriechel, Cordelia Reimers and Inge Sieben for helpful comments on earlier versions of this paper. 



\section{Introduction}

Policy makers in most OECD countries are very concerned about the risks of skill obsolescence in the current 'knowledge economy' (e.g. European Commission, 2000). The risk of skill obsolescence is thought to be particularly great in industries that use rapidly changing technologies. One of the consequences that are most feared is that such skill obsolescence will lead to increasing job insecurity over the life course, making it difficult to maintain an adequate level of labor market participation of older workers. This has in turn contributed to the interest in the phenomenon of life-long learning, as a potential remedy for the ills of skill obsolescence.

In this article we seek to analyze whether technological change induces skill obsolescence, and how this is related to lifelong learning. Our analyses focus on older Dutch workers (aged between 40 and 62). We will develop and test two conceptual models on the effects of technological change, training and on-thejob learning on the chance of losing one's job. The first model is a static model, in which training participation and on-the-job learning are exogenous. This model reflects the conventional wisdom on skill obsolescence. The second model is a dynamic model in which skill obsolescence and life-long learning mutually reinforce each other, driven by technological change that takes place in the workplace. The latter model predicts that when workers experience skill obsolescence more or less continuously in their job, this may indicate a healthy dynamic situation in which technological change and the concomitant learning potential of the job create their own learning process.

Particularly in the greying economies of the member states of the European Union, sustaining the labor market participation of older workers is a critical issue. In these countries, the labor market participation of older male workers decreased dramatically in the last two decades of the twentieth century (OECD, 1999). Although the decision to stop working is often made by the worker him/herself, such 'voluntary' retirement is often a result of decreasing productivity rather than a simple expression of one's own preferences (Campbell, 1999). Older workers may face a decreasing productivity due to rapid changes in the world of work. The main motor of such change is the 
increasingly complex technology that is being used in many industries. It is more or less inevitable that this will lead to changes in the nature of jobs, and in the skills required to perform in these jobs. The literature on skill-biased technological change (e.g. Card \& DiNardo, 2002; DiPrete, 2005) shows that the use of advanced technology induces an upward shift in the skill-structure of employment, whereas other authors found that technological change affects the relative demand for different skills (Dickerson \& Green, 2004). Partly as a result of such changes, the skills workers already possess will tend to lose their relevance for the labor market, and their place will be taken by skills that were previously less important or not required at all (Welch \& Ureta, 2002). Pension schemes often encourage early retirement of workers whose productivity is waning. In such cases, the decision to retire is not strictly voluntary (OECD, 2001). The same device is often applied when workers are no longer able to do their job properly due to physically or mentally demanding working conditions (Van Loo, De Grip \& De Steur, 2001). In this sense, the prevailing institutions for early pensioning or disability benefits are to a large extent endogenous to workers' risk of skill obsolescence.

If nothing is done to mitigate the negative effects of this job-specific skill obsolescence, we would expect the match between a worker's available skills and the skills required for the job to deteriorate steadily over the life course. Other things being equal, it seems natural to expect this problem to be most severe in those jobs and sectors that are most strongly affected by the use of advanced technology. Older workers are thought to be particularly vulnerable to the negative effects of changes in the content of the job on the value of their human capital, as older workers possess less recent vintages of human capital and might suffer from accumulated skill obsolescence. Neuman \& Weiss (1995) argue that this particularly holds for more skilled workers. In addition, psychological literature shows that older workers - in this case particularly those with low levels of education - are more susceptible to cognitive decline (Bosma et al. 2003) and may have more difficulty in responding to change than younger workers. Older workers also have a shorter time in which to recoup the benefits of any human capital investments made to cope with changing job contents, and usually face less social stigmatization should they choose to cease actively participating in the labor market. 
The remedy that is most commonly prescribed for the adverse effects attributed to skill obsolescence is to make additional investments in human capital. This remedy is nowadays often referred to by the notion of lifelong learning. Although such investments can take different forms, most research focuses on the effects of formal training. To the extent that informal learning is taken on board, it is largely treated in the same way as formal training, namely as a oneway flow of knowledge from an experienced supervisor to his/her less experienced subordinate. A problem with this one-sided focus on formal or semi-formal learning is that it ignores the fact that learning often takes place as a by-product of simply doing one's job. An important implication of this is that workers are learning more or less all the time, and not just during periods of formal training or semi-formal instruction. This has implications not just for the analysis of lifelong learning as a remedy for skill obsolescence, but also for the way in which obsolescence itself is conceived. Most scholars implicitly treat skill levels of workers as essentially static states interrupted by discrete intervals of formal training. When we take spontaneous informal learning into account, it becomes clear that workers' skills are changing continuously. If such changes are more or less randomly distributed across jobs and firms, this could be dismissed as random noise, and the prevailing models could be regarded as useful simplifications that focus the analyses. However, learning is likely to be anything but random. Jobs may be deliberately structured so as to provide learning opportunities (e.g. Eraut, 2000). The learning potential of the job (Rosen, 1972) is likely to be greatest in cases where the learning of new skills is deemed most necessary, namely in precisely those jobs where skill requirements are also changing rapidly. Whereas jobs characterized by repetitiveness, hierarchical control mechanisms and low levels of autonomy may stifle learning opportunities for workers, more complex jobs with shifting job contents offer ample opportunities for lifelong learning.

\section{Two Models of skill Obsolescence}

In this paper we start from the assumption that the performance of a given worker in a given job is a function of the overlap between the skills actually 
possessed by a worker and the skills needed to do the job. This worker-job matching assumption (e.g. Jovanovic, 1979), can be summarized in Figure 1.

Figure 1

Worker-job matching

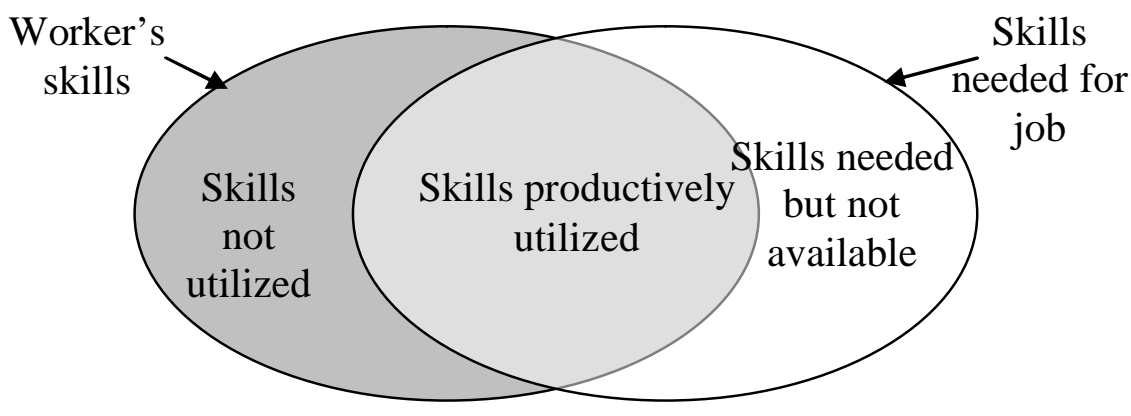

The figure distinguishes on the one hand a worker's skills that overlap with the skills that are needed. Only these skills actually contribute to the worker's performance in that job. In contrast, the other part of the worker's skills is not needed in the job where he or she is employed. These skills cannot be productively utilized in the job and thus do not contribute to the worker's performance. The same holds for the skills that are needed to do the job but that are not possessed by the worker, i.e. the worker's skill shortage.

Over time, technological change can induce shifts in the skills needed to perform in a given job. If we assume for the moment that the worker's own skill level remains relatively static, this will change the worker-job match. This is shown in Figure 2.

\section{Figure 2}

Shifts in required skills as a result of technological change
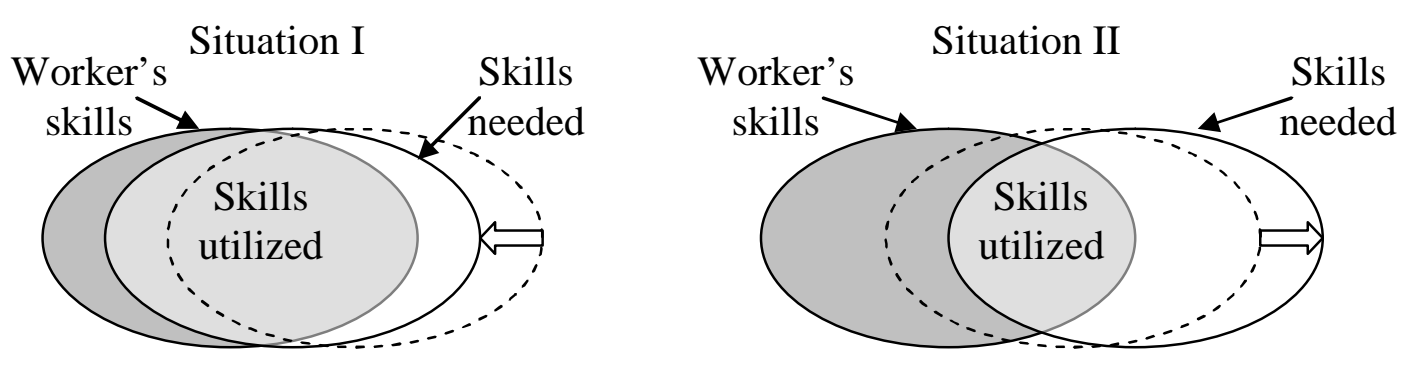
In principle, the shift in the skills needed in the job can be in any direction with respect to the existing skills of the incumbent. This means that changes in the job resulting from technological change can lead to either an improvement (Situation I) or deterioration (Situation II) in the match between actual and required skills. However, there are vastly more ways in which a change can lead to deterioration in the match than ways in which a change leads to an improvement. Consequently, it is safe to assume that in the aggregate the change will lead to a decrease in the volume of skills that are productively utilized.

Such a change has serious consequences for both the employee and the employer. From the point of view of the employee, underutilization of skills has strong unwanted effects on productivity and earnings (see for example Sicherman, 1991; Hersch, 1991; Cohn and Khan, 1995; Van Smoorenburg and Van der Velden, 2000), as well as on job satisfaction (Tsang and Levin, 1985; Allen \& Van der Velden 2001). By contrast, the major concern of employers will be about skill shortages, which lead directly to loss of potential output. In the ensuing discussion, we will concentrate on effects relating to skill shortages.

As a result of the deterioration in a worker's performance the worker's hold on his or her job may become less secure. Compared to the initial situation, the employer has a greater incentive to dismiss the current worker, and replace him or her by a worker with more appropriate skills. Because such changes are often market or context driven, the worker's prospects of obtaining a similar or better position after dismissal are not favorable. We would therefore expect the increased skill gap to increase the risk that the worker has to move to a worse job, or lose employment altogether. This risk is likely to be particularly great in those European countries such as the Netherlands where demand shifts away from unskilled labor tend to be absorbed more by relaxing job security than through wage adjustments (Maurin \& Postel-Vinay, 2005).

There are of course less drastic measures that can be used to reduce the skill gap following technological change. Where change is accompanied or followed by formal training, or by on-the-job learning, this can offset the negative effects of the change in required skills. This is shown in Figure 3. 
Figure 3

The effects of formal or informal learning following technological change

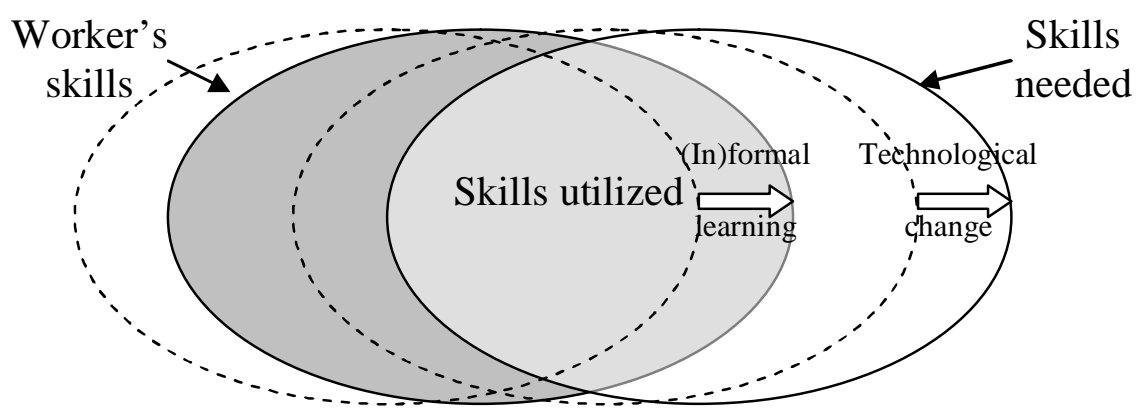

If the acquisition of new skills is sufficient to at least offset the shift in skill requirements as a result of technological change, the worker's job security is not likely to be compromised, and may even improve. However, if formal or informal learning does not take place, or is insufficient to offset the shift in requirements, the worker may face an increasing risk of losing his or her job. Recalling that this conceptualization of the relation between technological change, skill obsolescence and formal or informal learning is based on the assumption that the worker's own skills remain relatively static except during periods of formal training or informal instruction, we call this the static model of skill obsolescence. This model is shown in Figure 4:

Figure 4

Static model of skill obsolescence and employment loss

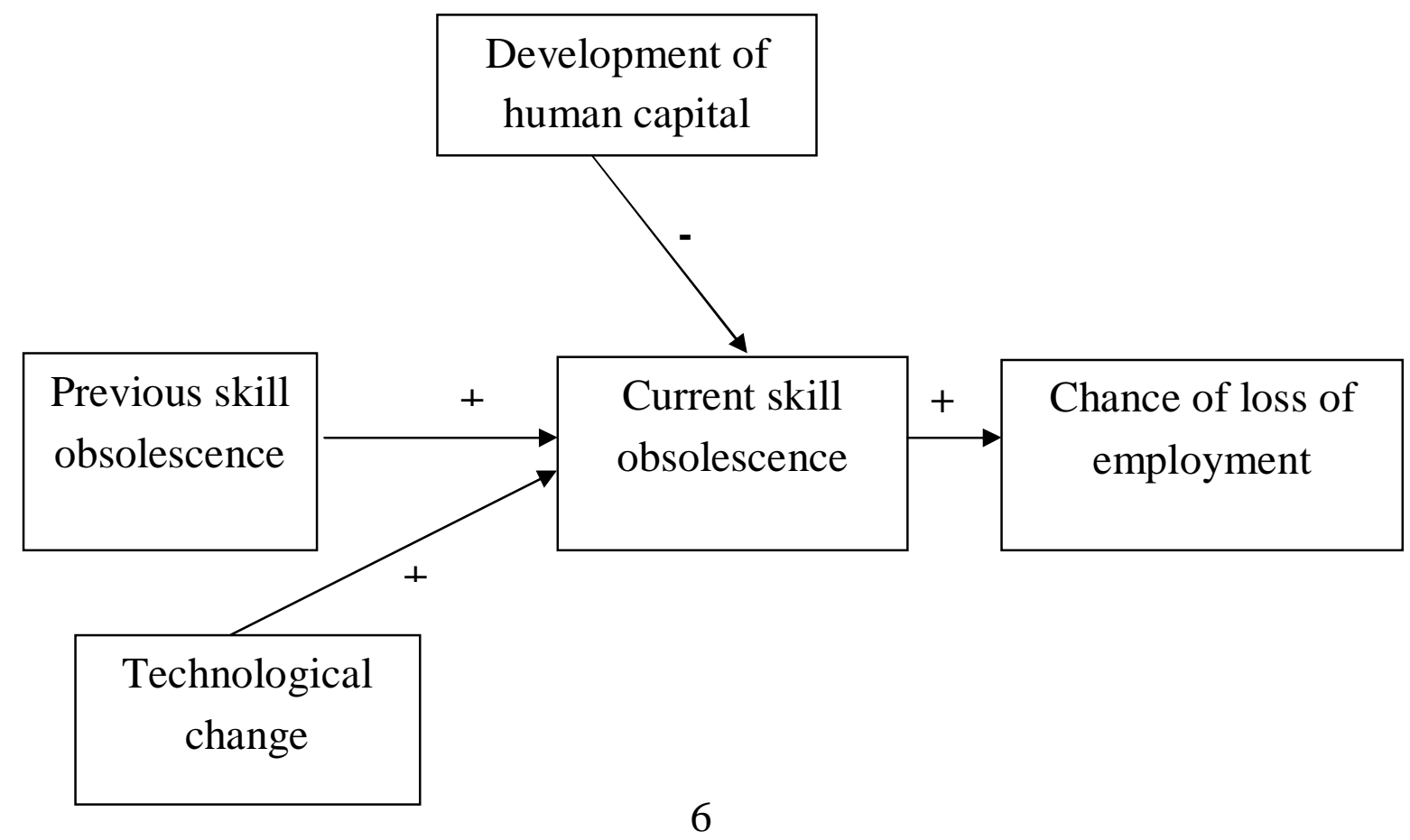


If we drop the assumption that skill levels are static, a different model of the relation between technological change, skill obsolescence and labor market participation arises. Both the decision to train and the decision to organize work in such a way as to promote learning by doing may not be independent of technological change. Changes that are expected to give rise to skill mismatches according to the static model may even create their own learning situation: workers in organizations undergoing change are likely to be exposed to a wider variety of experiences from which they can learn new skills. In addition, both employers and workers may respond or anticipate the changes in technology by making greater investments in training. In other words, workers may more or less automatically learn new skills as the requirements arise. This suggests that, rather than a situation in which the size of the skill gap after change is dependent on investments in training and on-the-job learning, these investments may in fact be dependent on the size of the initial skill gap and the new skill requirements resulting from technological change. This is shown in figure 5.

\section{Figure 5}

Formal and informal learning endogenously related to technological change

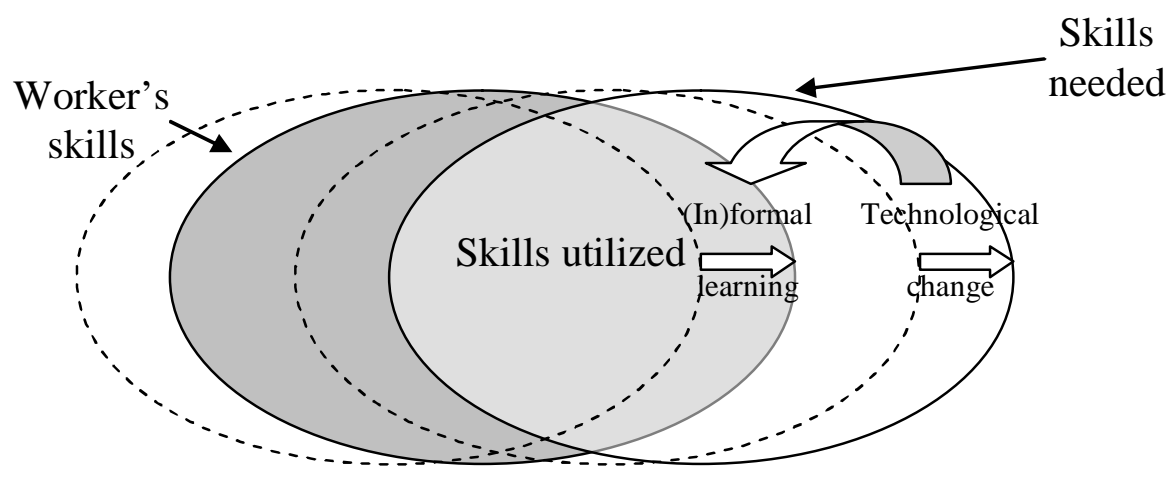

If formal and informal learning are indeed endogenous to technological change, this also changes the expected relation between obsolescence and labor market participation. If workers in changing organizations are continuously updating their skills to meet the changing requirements, they should be no more at risk of losing their jobs than workers in more stable organizations. This dynamic model is summarized in Figure 6. 


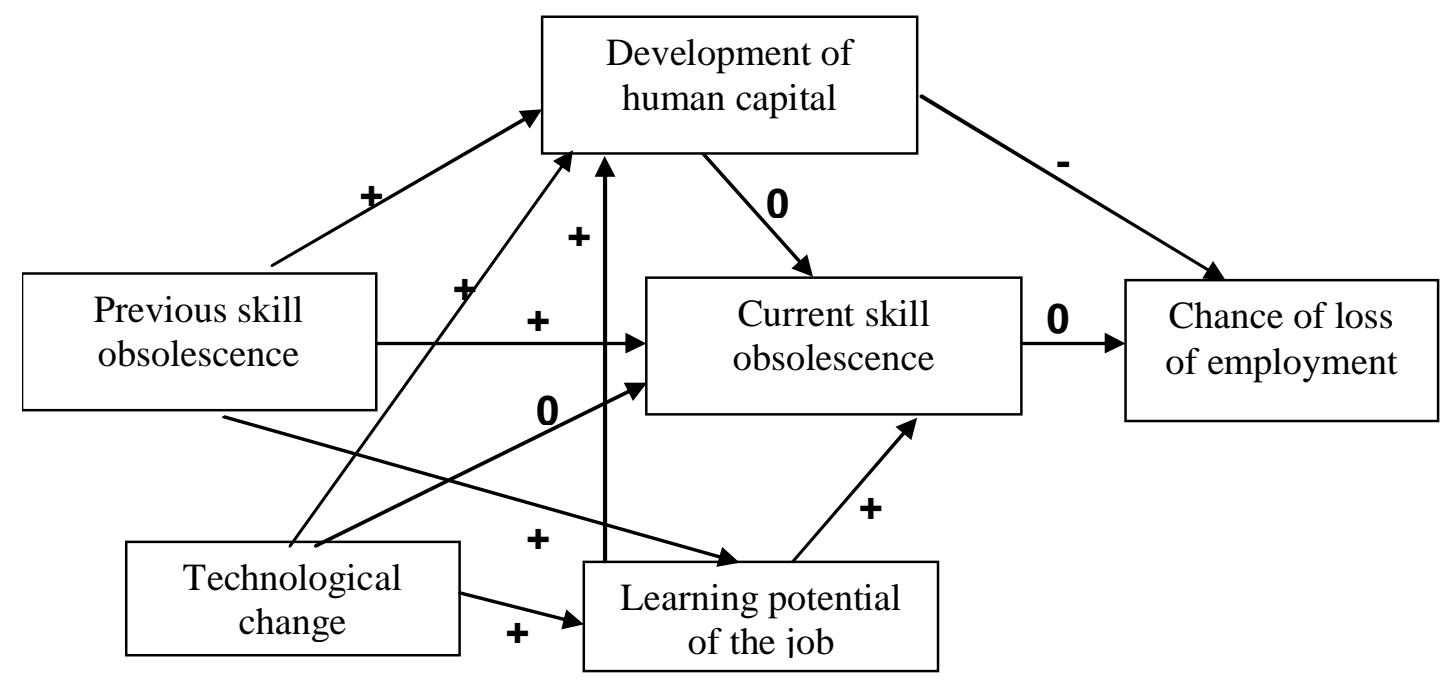

The figure shows that of the effects predicted by the static model, only the predicted positive relation between previous and current skill obsolescence remains in the dynamic model. However, even this superficial similarity might have a different interpretation in the two models. Whereas the static model views previous obsolescence as a burden that has to be overcome above and beyond the additional obsolescence induced by technological change, the dynamic model implies that, in some cases at least, skill obsolescence is a more or less structural characteristic of the job. Far from being a problem, in such jobs the perceived 'obsolescence' may be an indication of a healthy and dynamic situation. As 'old obsolescence' is eliminated by investments in training and/or on the job learning, 'new obsolescence' will pop up to take its place. If this is the case, this has some important implications. Firstly, training participation will not reduce the skills gap, and - depending on the ratio of this kind of obsolescence to the more conventional, problematic kind - may even be positively related to the skill gap measured after the training. Secondly, the skill obsolescence perceived by the worker will not increase a worker's risk of loss of work. Thirdly, although the dynamic model predicts no indirect effect of training, it does predict a direct effect. This is because training is regarded as an investment, which both employers and employees would like to recoup by extending the employment relationship. 


\section{Data and variables}

\section{Data}

For our analyses on the relationships between technological change, skill obsolescence and investments in human capital, we make use of data from the OSA Labor Supply Panel. The OSA Labor Supply Panel consists of a representative biannual survey among a representative sample of the Dutch working age population. Due to the relatively high rate of panel attrition, which is compensated by adding new respondents in each new wave, we only use the panel character of the OSA data in a limited way. In order to increase the number of available cases in the analyses - which is particularly important because most of the dependent variables we consider are quite heavily skewed dummy variables - we treat each wave as an independent sample, and pool data over the three successive waves of 1994, 1996 and 1998. To the data for each of these waves we add an indicator of skills obsolescence for the same respondents two years earlier, as well as an indicator of their labor market participation two years later. For example, the data for working respondents in the 1994 wave includes information on whether or not they suffered from skills obsolescence in 1992, and on whether or not they were still in paid employment in 1996. This is shown schematically in Figure 7.

\section{Figure 7}

The three waves used, including previous skill obsolescence and subsequent labor market participation

\begin{tabular}{|c|c|c|c|c|}
\hline 1992 & 1994 & 1996 & 1998 & 2000 \\
\hline \multirow{5}{*}{$\begin{array}{l}\text { Previous skill } \\
\text { obsolescence }\end{array}$} & \multirow{3}{*}{$\begin{array}{c}\text { Main body of } \\
\text { variables - } 1994 \\
\text { wave }\end{array}$} & $\begin{array}{c}\text { Subsequent labor } \\
\text { market } \\
\text { participation }\end{array}$ & & \\
\hline & & \multirow{3}{*}{$\begin{array}{c}\text { Main body of } \\
\text { variables }-1996 \\
\text { wave }\end{array}$} & $\begin{array}{c}\text { Subsequent labor } \\
\text { market } \\
\text { participation }\end{array}$ & \\
\hline & & & \multirow{3}{*}{$\begin{array}{c}\text { Main body of } \\
\text { variables }-1998 \\
\text { wave }\end{array}$} & $\begin{array}{l}\text { Subsequent labor } \\
\text { market participation }\end{array}$ \\
\hline & $\begin{array}{l}\text { Previous skill } \\
\text { obsolescence }\end{array}$ & & & \\
\hline & & $\begin{array}{l}\text { Previous skill } \\
\text { obsolescence }\end{array}$ & & \\
\hline
\end{tabular}


The data from the three waves is pooled, resulting in a pooled data set containing 4,683 usable cases, comprising a main body of variables in the reference year, with the relevant variables from the previous and subsequent waves appended. This is shown in Figure 8.

\section{Figure 8}

The pooled dataset ${ }^{2}$

\begin{tabular}{|c|cc|}
\hline Previous skill obsolescence & Main body of variables & Subsequent labor market participation \\
\hline 1992 & 1994 & 1996 \\
+ & + & + \\
\hline 1994 & 1996 & 1998 \\
+ & + & + \\
\hline 1996 & 1998 & 2000 \\
$=$ & $=$ & $1996+1998+2000$ \\
\hline $1992+1994+1996$ & $1994+1996+1998$ & \\
\hline
\end{tabular}

In order to focus on the part of the workforce that is most at risk of losing its place in the labor market due to skill obsolescence, we include only respondents aged between 40 and 62 at the time of the survey. The reason for choosing 62 as an upper bound was that then all respondents are still below the official mandatory retirement age of 65 two years later, when we again measure their labor market participation. ${ }^{3}$

\section{Variables}

In the analyses, skill obsolescence (both in the previous and current periods) is indicated by respondents who reported either an 'obsolescence' of the skills they acquired in the past or a 'skill shortage' in the period in question. According to De Grip \& Van Loo (2002), the former refers to technical obsolescence or depreciation of skills, and the latter to economic skill obsolescence.. Loss of work is indicated by respondents who were in paid

2. Because we pool data from different years, some respondents are represented more than once in the data. The data contain a total of 2,594 individual respondents, of which 1,211 appear once, 677 twice and 706 in all three survey years. To correct for the multiple occurrence of individual respondents we use the 'Cluster' option in STATA to estimate robust standard errors in our multivariate analyses.

3. For more information on the OSA Panel, see http://www.tilburguniversity.nl/osa/datasets. 
employment in the reference period but not two years later. Technological change is indicated by IT-intensity: the percentage of employees in the respondent's occupational group who used a personal computer in their work. At first sight, one might wonder whether an aggregate measure of computer use adequately captures the kind of change we are interested in. We argue that an aggregate measure is in fact more appropriate than an individual measure, since a computer-intensive infrastructure forms part of the environment that allows or forces - firms to innovate.

Moreover, we include the variable induction time - the time that the respondent expects to be needed for a comparably educated new employee to learn how to do the job - as an indicator of the learning potential of the job. On the basis of the dynamic model, we assume that jobs that require a lot of initial learning are knowledge or skill-intensive jobs, of which learning is more or less a structural characteristic. Of course, this assumption does not hold according to the static model, which if anything would predict that a lot of learning early on would reduce the need for later learning. This contrast makes this variable especially suitable for a comparison of the two models. Training participation (both previous and current) is indicated by (the natural logarithm of) the number of courses followed in the relevant two-year period. In the case of previous training this is the two years prior to the reference year. In the case of current training it is the period of a year prior and a year subsequent to the reference period. ${ }^{4}$ As control variables in several analyses we include tenure (both a linear and a quadratic term), occupational level, gender, age, cohort (survey year), and firm size. Table 1 contains a description of the variables used in the analysis. ${ }^{5}$

4. We use two different indicators of training, which play two different roles in our analyses. Training in the previous period is used as a predictor of current skill obsolescence and the chance of losing one's work. Training in the current period is used as a dependent variable, with among other things the percentage of computer use, the initial training time needed in the job and previous skill obsolescence as predictors. The fact that these two variables overlap partly does not present a problem, because they never appear together in any analyses.

5. A full description of the way in which the variables have been operationalized is presented in Appendix 1. 
Table 1

Descriptive statistics of variables used in the analyses

\begin{tabular}{|c|c|c|c|}
\hline Variable & $\%$ & Mean & $\begin{array}{l}\text { Standard } \\
\text { deviation }\end{array}$ \\
\hline Skill obsolescence & 4.4 & - & - \\
\hline Loss of work & 6.8 & - & - \\
\hline IT-intensity (\% in occupational group) & - & 57.63 & 31.42 \\
\hline Previous training participation (number of courses followed) & - & 0.41 & 0.85 \\
\hline Current training participation (number of courses followed) & - & 0.43 & 0.90 \\
\hline Induction time & - & 6.42 & 2.27 \\
\hline Prior skill obsolescence & 5.6 & - & - \\
\hline Tenure (years) & - & 14.27 & 10.09 \\
\hline \multicolumn{4}{|l|}{ Occupational level: } \\
\hline - Low & 35.7 & - & - \\
\hline - Intermediate & 32.9 & - & \\
\hline - High & 31.4 & - & - \\
\hline Gender (female) & 37.4 & - & - \\
\hline Age & - & 48.07 & 5.49 \\
\hline \multicolumn{4}{|l|}{ Cohort: } \\
\hline - 1994 & 30.5 & - & - \\
\hline - 1996 & 32.1 & & \\
\hline - 1998 & 37.4 & - & - \\
\hline \multicolumn{4}{|l|}{ Firm size: } \\
\hline - $\quad<10$ employees & 19.6 & - & - \\
\hline - $\quad 10-99$ employees & 39.0 & & \\
\hline - $>=100$ employees & 41.4 & - & - \\
\hline
\end{tabular}

\section{Empirical analyses}

In the analyses that follow, we will test the applicability of the static and the dynamic model of the relations between technological change, human capital development, skill obsolescence and loss or employment. First, we analyze the determinants of the skill obsolescence workers perceive in their current job. Second, we analyze the determinants of workers' probability of unemployment or labor market withdrawal in the subsequent period. As the results of these analyses support the dynamic model, we further test two other predictions of this model, namely that technological change and previous skill obsolescence 
are related to the learning potential of their job, and to investments in training.

\section{A. Current Skill Obsolescence}

In the first analysis, we look at the effects of various characteristics on the probability that one is subject to skill obsolescence in the current period. According to the static model, this will be positively related to both previous skill obsolescence and IT-intensity, and negatively related to training participation. The dynamic model also predicts a positive effect of previous obsolescence - albeit for a different reason - but predicts no significant effect of either IT-intensity or training participation. This model does predict a positive effect of induction time. The results of the analysis of the skill obsolescence workers perceive in their job are presented in Table 2.

\section{Table 2}

Logit estimation of skill obsolescence in the current job

\begin{tabular}{|c|c|c|}
\hline & B & Robust S.E. \\
\hline Constant & $-3.133^{\star \star}$ & 0.823 \\
\hline IT-intensity & 0.004 & 0.003 \\
\hline Previous training participation & 0.021 & 0.034 \\
\hline Induction time & $0.118^{* \star}$ & 0.043 \\
\hline \multicolumn{3}{|l|}{ Previous skill obsolescence } \\
\hline & $1.502^{* \star}$ & 0.224 \\
\hline \multicolumn{3}{|l|}{ Tenure } \\
\hline \multirow[t]{2}{*}{ Tenure-squared } & 0.012 & 0.026 \\
\hline & -0.059 & 0.078 \\
\hline \multicolumn{3}{|c|}{ Occupation level (reference category intermediate level) } \\
\hline \multirow[t]{2}{*}{ - High level } & -0.409 & 0.222 \\
\hline & -0.261 & 0.174 \\
\hline \multicolumn{3}{|l|}{ Gender (female) } \\
\hline & -0.171 & 0.173 \\
\hline \multicolumn{3}{|l|}{ Cohort (reference 1996) } \\
\hline • 1994 & -0.117 & 0.172 \\
\hline - 1998 & $-0.665^{\star \star}$ & 0.187 \\
\hline Age & -0.009 & 0.015 \\
\hline \multicolumn{3}{|c|}{ Firm size (reference category 10-99 employees) } \\
\hline - $\quad<10$ employees & -0.106 & 0.213 \\
\hline - $\quad>=100$ employees & -0.195 & 0.165 \\
\hline
\end{tabular}

$\mathrm{N}=4,528$; Pseudo R-sq: $0.053 ;{ }^{*}=\mathrm{p}<0.05 ;{ }^{\star \star}=\mathrm{p}<0.01$

SOURCE: OSA Labor Supply Panel, 1992-2000 
The estimation results provide strong support for the dynamic model, and little or no support for the static model. The only result that is consistent with the static model - that previous skill obsolescence is a strong predictor of current skill obsolescence - is also predicted by the dynamic model. However, contrary to the predictions of the static model but consistent with those of the dynamic model, IT-intensity and training participation have no effect, while induction time has a positive effect on current skill obsolescence.

\section{B. Loss of work}

Having established that the pattern of determinants of skill obsolescence is more consistent with the dynamic than with the static model, we now turn to the effects of skill obsolescence on the risk of loss of work in the subsequent period. The static model predicts that skill obsolescence will increase this risk substantially, as the loss of productivity related to obsolescence makes the worker's grip on employment increasingly tenuous. By contrast, the dynamic model predicts no such effect; because both obsolescence and learning are regarded as more or less structural characteristics of jobs, workers who experience obsolescence will not be more likely to lose their job than those who don't. Also in contrast to the static model is the predicted effect of training participation. According to the static model, any effect of training on the risk of losing one's work will be indirect, through its supposed effect on skill obsolescence. By contrast, the dynamic model predicts a direct negative effect of training participation on losing one's job. This is because training is regarded as an investment, which both employers and employees would like to recoup by extending the employment relationship. Table 3 shows the results of this analysis.

Again, the results are more in line with the dynamic model than with the static model. Skill obsolescence has no effect on the risk of loss of work. On the other hand, training participation does significantly reduce the risk of loss of work. Even though training does not have a net effect on perceived skill obsolescence, it does reduce the risk of loss of work, as expected in the dynamic model. 
Table 3

Logit estimation of loss of work

\begin{tabular}{|c|c|c|}
\hline & B & Robust S.E. \\
\hline Constant & $-11.684^{\star \star}$ & 0.937 \\
\hline IT-intensity & 0.002 & 0.003 \\
\hline Previous training participation & $-0.116^{\star *}$ & 0.043 \\
\hline Induction time & -0.055 & 0.035 \\
\hline Skill obsolescence & 0.223 & 0.355 \\
\hline Tenure & $-0.066^{\star *}$ & 0.023 \\
\hline Tenure-squared & $0.179 * *$ & 0.062 \\
\hline \multicolumn{3}{|c|}{ Occupation level (reference category intermediate level) } \\
\hline - Low level & -0.030 & 0.192 \\
\hline - High level & -0.342 & 0.194 \\
\hline Gender (female) & $0.454^{* *}$ & 0.161 \\
\hline \multicolumn{3}{|l|}{ Cohort (reference 1996) } \\
\hline - 1994 & $0.356^{*}$ & 0.174 \\
\hline - 1998 & -0.019 & 0.193 \\
\hline Age & $0.180^{\star *}$ & 0.017 \\
\hline \multicolumn{3}{|c|}{ Firm size (reference category 10-99 employees) } \\
\hline - $\quad<10$ employees & -0.189 & 0.214 \\
\hline - $\quad>=100$ employees & 0.058 & 0.169 \\
\hline
\end{tabular}

$\mathrm{N}=4.683 ;$ Pseudo R-sq: 0.151

${ }^{*}=p<0.05 ;{ }^{* *}=p<0.01$

SOURCE: OSA Labor Supply Panel, 1992-2000

An interesting effect not directly predicted by either model is that of tenure. Tenure shows a negative linear effect and positive quadratic effect on the risk of loss of work. The negative linear effect suggests that, up to a point, additional experience in a job adds to security in that job. This could be related to progressive acquisition of human capital by learning on the job, but could also indicate that the legal claim to one's position gets stronger over time. However, as time progresses, the effect becomes weaker, eventually leading to a higher risk of job loss (although only after 19 years). This suggests that a concentration of experience in a particular job eventually leads to stagnation and lower employability in the longer term. Since we have controlled for age - which has the expected positive effect on the chance of loss of work related to (early) 
retirement -, this result cannot be attributed to life-cycle effects. Women also have a higher chance of loss of work than men.

\section{Induction time}

As the results so far strongly support the dynamic model, we will proceed by testing a number of more specific predictions of this model. The dynamic model predicts that technological change as well as previous skill obsolescence will contribute positively to the learning potential of their job as indicated by a worker's induction time. We need to emphasize here that induction time is not the actual induction time of the worker when he or she started in the job, but rather a "what if" variable estimating the time a hypothetical replacement would need to learn the ropes. There is therefore no problem of causality, which would be the case if the variable referred to actual induction time. The dynamic model predicts that both IT-intensity and previous skill obsolescence will positively affect this variable. These predictions are borne out by the results of the analysis, shown in Table 4.

\section{Table 4}

Regression analysis of induction time

\begin{tabular}{|c|c|c|}
\hline & $\mathrm{B}$ & Robust S.E. \\
\hline Constant & $5.438^{\star *}$ & 0.430 \\
\hline IT-intensity & $0.009^{\star *}$ & 0.002 \\
\hline Previous skill obsolescence & $0.454^{\star *}$ & 0.175 \\
\hline \multicolumn{3}{|c|}{ Occupation level (reference category intermediate level) } \\
\hline - Low level & $-1.317^{* *}$ & 0.116 \\
\hline - High level & 0.126 & 0.101 \\
\hline \multirow{2}{*}{\multicolumn{3}{|c|}{$\stackrel{\bullet}{\text { Cohort (reference 1996) }}$}} \\
\hline & & \\
\hline • 1994 & $0.313^{\star *}$ & 0.073 \\
\hline - 1998 & $0.166^{*}$ & 0.081 \\
\hline Age & 0.013 & 0.008 \\
\hline \multicolumn{3}{|c|}{ Firm size (reference category 10-99 employees) } \\
\hline - $\quad<10$ employees & -0.199 & 0.139 \\
\hline - $\quad>=100$ employees & $0.285^{\star *}$ & 0.092 \\
\hline
\end{tabular}

$\mathrm{N}=3.130 ;$ Adjusted R-sq : 0.154

${ }^{*}=\mathrm{p}<0.05 ;{ }^{* *}=\mathrm{p}<0.01$

SOURCE: OSA Labor Supply Panel, 1992-2000 


\section{Training participation}

A final prediction of the dynamic model is that training participation is also endogenously influenced by both previous obsolescence and by IT-intensity. In addition, the model predicts that the learning potential of the job as indicated by the induction time will have a positive effect on training. Table 5 shows the results of the linear regression analysis.

\section{Table 5}

Regression analysis of training participation

\begin{tabular}{|c|c|c|}
\hline & B & Robust S.E \\
\hline Constant & $-2.293^{\star \star}$ & 0.478 \\
\hline IT-intensity & 0.002 & 0.002 \\
\hline Previous skill obsolescence & $0.597^{\star}$ & 0.233 \\
\hline Induction time & $0.129^{* *}$ & 0.020 \\
\hline Tenure & $0.027^{*}$ & 0.015 \\
\hline Tenure-squared & $-0.100^{\star *}$ & 0.042 \\
\hline \multicolumn{3}{|c|}{ Occupation level (reference category intermediate level) } \\
\hline - Low level & $-0.316^{\star *}$ & 0.122 \\
\hline - High level & 0.020 & 0.123 \\
\hline \multicolumn{3}{|l|}{ Cohort (reference 1996) } \\
\hline - 1994 & $-0.320^{\star *}$ & 0.081 \\
\hline - 1998 & -0.045 & 0.064 \\
\hline Age & $-0.035^{\star \star}$ & 0.009 \\
\hline \multicolumn{3}{|c|}{ Firm size (reference category 10-99 employees) } \\
\hline - $\quad<10$ employees & $-0.496^{\star *}$ & 0.122 \\
\hline - $\quad>=100$ employees & 0.089 & 0.111 \\
\hline
\end{tabular}

$\mathrm{N}=3.235 ;$ Adjusted R-sq : 0.060

${ }^{*}=p<0.05 ;{ }^{* *}=p<0.01$

SOURCE: OSA Labor Supply Panel, 1992-2000

The prediction that technological change leads to greater levels of training participation is not confirmed by the analysis. Workers in IT-intensive occupations are not more likely to invest in formal training than other workers. As the model predicts however, workers' training participation is influenced by prior skill obsolescence, as well as by induction time. This latter finding reinforces the view that learning requirements and opportunities are a structural characteristic of certain jobs. Even in the case of older workers we analyze, the 
tendency to invest in training is strongly related to the learning potential of their job.

Of further interest are the observed effects of tenure and tenure squared, which are more or less a mirror image of those seen for loss of work. This is suggestive of a pattern by which workers initially become more secure in their jobs, during which time they are more likely to invest in training. In time, however, both the trend towards increased job security and towards increased training is reversed. Whereas the effect of job tenure on the probability to lose one's job becomes positive after 19 years (see table 3), the effect of job tenure on training participation becomes negative after 13 years. These results show that when workers with long tenures decrease their efforts to keep their skills up-to-date, this is an early indicator of job loss due to a concentration of experience.

\section{Conclusions}

In this paper we developed a static as well as a dynamic model to explain the relationships between technological change, skill obsolescence, formal and informal learning and labor market exit. The static model treats learning processes as exogenous, and assumes a basically sequential causal chain, whereby technological innovations give rise to skill obsolescence that, in the absence of compensatory learning, leads to an increased risk of early exit from the labor market. By contrast, the dynamic model treats learning processes as endogenous to organizations that face a need to develop and change. In this model, skill obsolescence is largely structural by nature. That is to say, changes in skill requirements and the learning of new skills keep each other roughly in balance. As a consequence, this model does not predict an effect of skill obsolescence on the probability of early labor market exit.

The results of our empirical analyses provide virtually no support for the static model. The only result that was consistent with this model - that previous skill obsolescence is positively related to current skill obsolescence - is also predicted by the dynamic model. The other predictions of the static model are not borne out by the analyses. Workers in IT-intensive occupations are not more 
likely to suffer from skill obsolescence than workers in less IT-intensive occupations. Nor does training participation reduce obsolescence. Finally, and most tellingly, workers' skill obsolescence has no significant effect on the risk of loss of employment in the following period.

We obviously found more evidence for the dynamic model. The abovementioned absence of an effect of skill obsolescence on the chance of loss of work is consistent with this model. Whereas the static model views previous obsolescence as a burden that has to be overcome above and beyond the additional obsolescence induced by technological change, the dynamic model implies that skill obsolescence may be a more or less structural characteristic of many jobs. Moreover, training participation was found to have a significant negative effect on the chance of loss of work. Contrary to the predictions of the static model, this effect is not indirect, through a reduction of skill obsolescence, but rather direct. This is consistent with the idea, incorporated in the dynamic model, that the training that is related to technological innovations represents an important investment in human capital, which employers and employees have an interest in recouping through a longer employment duration (cf. Bartel \& Sicherman, 1993). A similar result is observed for job tenure, that proxies the net productivity effect of a worker's experience in the job. Initially, longer job tenure has a negative effect on the chances of loss of employment, indicating that workers accumulate valuable additional human capital through work experience. This effect decreases over time, however, and after about 19 years additional years of tenure actually increase the chance of losing employment, indicating that the experience build-up no longer dominates the depreciation of the worker's skills.

A key element in the dynamic model is the learning potential of a job, indicated in our analysis by induction time. This was found to be a strong determinant of skill obsolescence. Moreover, induction time has a positive influence on training participation. IT-intensive occupations are much more likely to have a long induction time. These results are consistent with the idea that learning potential, skill obsolescence, and investments in training and informal learning are all more or less structural elements of jobs that are highly challenging and dynamic. In this view, the skill obsolescence that workers in these jobs perceive 
may remain relatively constant: as new skills are acquired to fill a prior skill gap, new requirements are thrown up, which necessitates further learning in a subsequent period. Because this is driven by changes that increase the net productive potential of jobs, this does not lead to an increased risk of loss of employment. Instead, by stimulating further investments in the human capital of workers, it decreases the probability that workers lose their employment. The only result that was not consistent with the dynamic model was the lack of an effect of IT-use on the amount of training followed.

\section{Literature}

Allen, J. \& Velden, R. van der (2001) Educational Mismatches versus Skills Mismatches: Effects on Wages, Job Satisfaction and On-the-job Search. Oxford Economic Papers, 53, 434-452.

Bartel, A.P. \& Sicherman, N. (1993) Technological Change and Retirement Decisions of Older Workers. Journal of Labor Economics, 11, 162-183.

Bosma, H., Boxtel, M.P.J. van, Ponds, R.W.H.M., Houx, P.J.H. \& Jolles, J. (2003) Education and Age-related Cognitive Decline: The Contribution of Mental Workload. Educational Gerontology, 29, 165-173.

Campbell, N. (1999) The Decline of Employment Among Older People in Britain, London: Centre for Analysis of Social Exclusion, London School of Economics, CASE Paper 19.

Card, D. \& DiNardo, J.E. (2002) 'Skill-Biased Technological Change and Rising Wage Inequality: Some Problems and Puzzles', Journal of Labor Economics, 20, 4, 733-783.

Cohn, E. \& Khan, S.P. (1995) 'The Wage Effects of Overschooling Revisited', Labour Economics, 2, 67-76.

De Grip, A. \& Van Loo, J. van (2002) The Economics of Skills Obsolescence: A review. In: A. de Grip, J. van Loo \& K. Mayhew (eds.) The Economics of Skills Obsolescence: Theoretical Innovations and Empirical Applications, Research in Labor Economics, 21, 1-26.

De Grip, A, Van Loo, J. \& Sanders, J. (2004). The Industry Employability Index: Taking account of supply and demand characteristics, International Labour Review, 143, 211-233.

Dickerson, A. \& Green, F. (2004). The growth and valuation of computing and other generic skills, Oxford Economic Papers, 56, 371-406.

DiPrete, T.A. (2005) 'Labor Markets, Inequality and Change: A European Perspective', Work and Occupations, 30, 2, 119-139.

Eraut, M (2000) 'Non-formal learning and tacit knowledge in professional work,' British Journal of Educational Psychology 70,113-136. 
European Commission (2000) Presidency Conclusions, Lisbon European Council 23 and 24 March 2000, Brussels.

Hersch, J. (1991) ,'Education Match and Job Match', Review of Economics and Statistics, 73, 140144.

Jovanovic, B. (1979) 'Job Matching and the Theory of Turnover', Journal of Political Economy, 87.972-990.

Maurin, E. \& Postel-Vinay, F. (2005) 'The European Job Security Gap', Work and Occupations, 32, 2, 229-252.

McQuaid, R.W, \& Lindsay, C. (2005). 'The Concept of Employability: Transcending the Orthodoxies of Supply and Demand, Urban Studies, 42, 197-219.

Neuman, S. \& Weiss, A. (1995) On the Effects of Schooling Vintage on Experience Earnings Profiles: Theory and Evidence. European Economic Review, 39(5), 943-955.

OECD (1999) Employment Outlook 1999, Paris: OECD.

OECD (2001) Economics and Finance of Lifelong Learning, Paris: OECD.

Rosen, S. (1972) Learning and Experience in the labor market, Journal of Human Resources, 7, 326342.

Rosen, S. (1975) Measuring the Obsolescence of Knowledge. In: F.T. Juster (ed) Education, Income and Human Behaviour (pp. 199-232). New York: Carnegie Foundation.

Sattinger, M. (1993), Assignment Models of the Distribution of Earnings, Journal of Economic Literature, 31, 851-880.

Sicherman, N. (1991), "'Overeducation" in the Labour Market', Journal of Labor Economics, 9, 101122.

Topel, R. (1986) 'Job Mobility, Search and Earnings Growth', Research in Labor Economics, 8, 199233.

Tsang, M. \& Levin, H. (1985) 'The Economics of Overeducation', Economics of Education Review, 4, 93-104.

Van Loo, J., De Grip, A., \& De Steur, M. (2001) Skills Obsolescence, Causes and Cures. International Journal of Manpower, 22, 121-137.

Van Smoorenburg, M.S.M. \& Van der Velden, R.K.W. (2000) 'The Training of School-leavers: Complementarity or Substitution?', Economics of Education Review, 19, 207-217.

Weisberg, B.A. (2002). New Technologies, Skills Obsolescence, and Skill Complementarity, in: A. de Grip, J. van Loo \& K. Mayhew (eds.) The Economics of Skills Obsolescence: Theoretical Innovations and Empirical Applications, Research in Labor Economics, 21, 101-118. 
Welch, F. \& Ureta, M (2002) The Obsolescence of Skill, in: A. de Grip, J. van Loo \& K. Mayhew (eds.) The Economics of Skills Obsolescence: Theoretical Innovations and Empirical Applications, Research in Labor Economics, 21, 51-81. 


\section{Appendix 1. Operationalization of variables used}

\begin{tabular}{|c|c|}
\hline Indicator & Operationalization \\
\hline $\begin{array}{l}\text { Skill } \\
\text { obsolescence }\end{array}$ & $\begin{array}{l}\text { Respondents who reported either skill obsolescence or skill shortage at the time of the } \\
\text { survey. }\end{array}$ \\
\hline $\begin{array}{l}\text { Prior skill } \\
\text { obsolescence }\end{array}$ & $\begin{array}{l}\text { Respondents who indicated that they felt they had either skill obsolescence or skil } \\
\text { shortage two years earlier. }\end{array}$ \\
\hline Loss of work & $\begin{array}{l}\text { Respondents who were in paid employment in the reference period but either } \\
\text { unemployed or no longer participating in the labor force were assigned a value } 1 \text {. Those } \\
\text { who were still in paid employment were assigned a value } 0 \text {. }\end{array}$ \\
\hline IT-intensity & $\begin{array}{l}\text { The percentage of employees per occupational group that used a personal computer at } \\
\text { work was calculated, using data from the Dutch Labor Force Survey (Enquête } \\
\text { Beroepsbevolking) of Statistics Netherlands. This was matched to the individual level } \\
\text { data using the occupational code at the 3-digit level as matching variable. }\end{array}$ \\
\hline $\begin{array}{l}\text { Current training } \\
\text { participation }\end{array}$ & $\begin{array}{l}\text { The natural logarithm of the number of courses followed between one year prior and one } \\
\text { year subsequent to the reference period. }\end{array}$ \\
\hline $\begin{array}{l}\text { Previous } \\
\text { training } \\
\text { participation }\end{array}$ & The natural logarithm of the number of courses followed in past two years. \\
\hline Induction time & $\begin{array}{l}\text { Answer to the question: "How long would it take somebody with a comparable education } \\
\text { who was newly employed by the firm to learn to perform your job well? ". }\end{array}$ \\
\hline Tenure & $\begin{array}{l}\text { Number of years in employment with current employer. Both a linear and quadratic term } \\
\text { included in the analyses. }\end{array}$ \\
\hline $\begin{array}{l}\text { Occupational } \\
\text { level }\end{array}$ & Low, medium and high level occupations are distinguished. \\
\hline Gender & Dummy variable equal to 1 for women, and 0 for men. \\
\hline Age & Age at time of survey \\
\hline Cohort & 1994,1996 or 1998. \\
\hline Firm size & $\begin{array}{l}\text { Three categories are distinguished: firms with less than } 10 \text { employees, firms with } 10 \text { to } \\
99 \text { employees, and firms with } 100 \text { or more employees. }\end{array}$ \\
\hline
\end{tabular}

